\title{
TANGGUNG JAWAB PENYELENGGARA TRANSAKSI ELEKTRONIK DALAM MELINDUNGI HAK KONSUMEN
}

\author{
Resna Pratiwi Maharani \\ Universitas Sahid Jakarta \\ resnapratiwy07@gmail.com
}

\begin{abstract}
ABSTRAK
Transaksi e-commerce pada dasarnya merupakan suatu kontrak perdagangan dengan menggunakan media internet. Undang-Undang tentang Informasi dan Transaksi Elektronik telah mengatur transaksi perdagangan secara elektronik. Dalam praktik, transaksi e-commerce masih memunculkan masalah terutama bagi konsumen, penyelesaian sengketa dalam praktik transaksi $e$ commerce merupakan alternatif solusi dalam mengatasi sengketa sekaligus dalam bentuk perlindungan hukum. Dalam tulisan ini akan membahas mengenai tanggungjawab penyelenggara transaksi elektronik dalam memenuhi prestasinya menurut peraturan perundang-undangan yang berlaku di Indonesia dan perlindungan konsumen dalam jual beli secara online. Penelitian ini menggunakan metode penelitian yuridis normatif. Hasil penelitian diperoleh kesimpulan bahwa Tanggungjawab penyelenggara transaksi elektronik dalam memenuhi prestasinya menurut peraturan perundang-undangan yang berlaku di Indonesia yaitu menurut UUPK meliputi tanggungjawab atas kerusakan, tanggungjawab atas pencemaran dan tanggungjawab atas kerugian konsumen. Apabila penyelenggara penjualan secara online tidak bertanggungjawab terhadap perbuatan wanprestasinya, maka konsumen dapat menempuh jalur hukum dengan mengajukan gugutan terhadap pelaku usaha sesuai dengan peraturan perundang-undangan yang mengatur mengenai perbuatan tersebut yakni KUHPer, UUPK, Undang-Undang ITE dan PP PSTE. Konsumen juga dapat menempuh jalur pidana dengan melakukan pelaporan terhadap pihak yang berwajib dengan tuduhan tindak pidana penipuan. Bentuk perlindungan konsumen dalam jual beli secara online telah diatur di dalam UUPK dan Undang-Undang ITE bahwa konsumen berhak mendapatkan informasi yang benar, jelas, dan jujur mengenai kondisi dan jaminan barang dan/atau jasa. Bentuk perlindungan konsumen juga meliputi sistem keamanan, pengembalian produk dan pengembalian dana yang sesuai dengan aturan hukum positif.
\end{abstract}

Kata kunci : Penyelenggara Transaksi Elektronik, Jual Beli, Konsumen.

\begin{abstract}
E-commerce transactions are basically a trading contract using internet media. The Electronic Information and Transaction Law regulates trade transactions electronically. In practice, e-commerce transactions still create problems, dispute resolution in the practice of e-commerce transactions is a solution alternative in dealing with disputes in the form of legal protection. In this paper we will discuss the responsibilities of providers of electronic transactions in fulfilling their achievements according to the laws and regulations in force in Indonesia and the protection of consumers in buying and selling online. This study uses a normative juridical research method. The results of the study concluded that the responsibility of the organizers of electronic transactions in fulfilling their performance according to the laws and regulations in force in Indonesia, according to the UUPK, includes responsibility for damage, responsibility for pollution and responsibility for consumer losses. If the online sales provider is not responsible for defaults, the consumer can take legal action by filing a lawsuit against the business actor in accordance with the laws and regulations governing the act. Consumers can also take the criminal route by reporting to the authorities on charges offraud. The form of consumer protection in online buying
\end{abstract}


and selling has heen regulated in the Law and Company Law that consumers have the right to ohtain correct, clear and honest information about the condition and guarantee ofgoods and I or Services. The form of consumer protection also includes security systems, product returns and refunds that are in accordance with the rules of positive law.

Keywords: Electronic Transaction Operator, Buy and Sell, Consumer.

\section{PENDAHULUAN A. LATAR BELAKANG}

Perkembangan dan kemajuan internet telah mendorong kemajuan di bidang teknologi informasi. Penggunaan internet yang semakin luas dalam kegiataan bisnis, industri dan rumah tangga telah mengubah pandangan manusia. Dimana kegiatan perdagangan pada awalnya dimonopoli oleh kegiatan fisik kini bergeser menjadi kegiatan di dunia maya (Cyber World) yang tidak memerlukan kegiatan fisik. Internet pertama kali muncul pada tahun 1969 di Amerika Serikat, dimana dibentuk suatu jaringan komputer di University of California di Los Angeles, University of California di Santa Barbara, University of Utah dan Institut Penelitian Stanford. Proyek yang didanai oleh Dapartemen Pertahanan Amerika Serikat dengan nama Advanches Researches Project Agence (ARPA), ARPA atau ARPANET ini didesain untuk mengadakan sistem desentralisasi internet. Pada tahun 1980, Yayasan Nasional Ilmu Pengetahuan (National Scince Foundation) memperluas ARPANET untuk menghubungkan komputer seluruh dunia. Era globalisasi merupakan perubahan global yang melanda seluruh dunia. Dampak yang teijadi sangatlah besar terhadap berbagai aspek kehidupan masyarakat, terjadi sangatlah besar terhadap berbagai aspek kehidupan masyarakat. Hal ini disebabkan adanya kemajuan ilmu pengetahuan dan teknologi yang akan mengubah pola perilaku konsumsi masyarakat.

Peranan teknologi informasi dan komunikasi di era globalisasi telah menempatkan pada posisi yang sangat strategis karena menghadirkan suatu dunia tanpa batas, jarak, ruang dan waktu yang berdampak pada peningkatan produktivitas dan efisiensi. Pengaruh globalisasi dengan penggunaan sarana teknologi informasi dan komunikasi telah mengubah pola hidup masyarakat, dan berkembang dalam tatanan kehidupan baru dan mendorong terjadinya pembahan sosial, ekonomi, budaya, pertahanan, keamanan, dan penegakan hukum. Persentuhan hukum dengan banyak aspek kehidupan manusia tersebut secara langung maupun tidak, telah menghasilkan suatu pembahan. Pembahan inilah yang menuntut hukum untuk selalu mengikuti serta berusaha mengimbanginya dengan cara melakukan suatu pembahan hukum untuk menyesuaikan dengan kondisi sosial masyarakat yang terjadi saat ini guna menciptakan hukum yang sesuai dengan kebutuhan dan cita-cita masyarakat.

Manusia sebagai pencipta, pengembang dan pengguna teknologi informasi dan komunikasi saat ini mengarah kepada sesuatu yang memudahkan pengguna itu sendiri, salah satunya dapat dilihat dari perkembangan media internet yang sangat pesat. Internet sebagai suatu media informasi dan komunikasi elektronik telah banyak dimanfaatkan untuk berbagai kegiatan, antara lain yaitu perdagangan. Kegiatan perdagangan dengan memanfaatkan media internet ini dikenal dengan istilah electronic commerce atau disebut e-commerce.

E-commerce merupakan suatu perjanjian jual 'beli yang sama dengan jual beli konvensional, perbedaannya hanya terletak pada media yang digunakan. Pada transaksi $e$ commerce yang dipergunakan adalah media elektronik yaitu internet. Sehingga kesepakatan ataupun perjanjian yangtercipta adalah melalui Online.

Peijanjian yang dilakukan secara Online pada dasarnya sama dengan perjanjian jual beli 
pada umumnya, peijanjian jual beli Online tersebut juga terdiri dari penawaran dan penerimaan. Suatu kesepakatan selalti diawali dengan adanya penawaran oleh salah sahi pihak dan penerimaan oleh piliak yang lainnya. Jual beli secara Online saat ini menjadi pilihan konsumen karena kemudahannya seperti yang ada pada sihis Lazada, Zalorra, Tokopedia. Transaksi jual beli melalui media internet ini menjadi alternatif yang menarik dan sangat diminati bagi konsumen pada saat ini. Konsumen tertarik melakukan transaksi melalui media internet ini karena dengan muda.hnya mencari barang yang diinginkan, membandingkan harga, kemudian beragam pilihan metode pembayaran yang ditawarkan, sehingga memudahkan konsumen dalam melakukan pem'belian tanpa harus keluar rumah, hal ini tenhi lebih efektif dan efisien karena transaksi dapat dilalmkan oleh setiap orang kapan saja dan dimana saja. Berdasarkan kelebihan tersebut tidak dipungkiri adanya risiko yang timbul dalam transaksi ini karena dilakukan tanpa ada pertemuan antara pihak manapun. Mereka mendasarkan transaksi jual beli ini atas -rasa kepercayaan sahi sama lain.

Transaksi jual beli secara umum diahn. dalam Kitab Undang-undang JJukum Pei'data yang selanjutnya disebut KUHPer buku III tentang perikatan, khususnya bab I sampai dengan bab V, tetapi secara khusus transaksi jual beli elektronik ini diatur dalam Undang-undang Nomor 11 Tahun 2008 tentang Informasi dan Transaksi Elektronik 2008 jo Undang-Undang Nomor 19 Tahun 2016 yang selanjutnya disebut Undang-Undang ITE. Kasus Pertama, Pada tanggal 23 Juiri 2015 seorang konsumen Lazada Indones-ia telah teijadi salah pengiriman barang atas nama Danis Darusman dengan nomor pemesanan \#377954652 membeli sebuah- iPhone 6 Plus yang menjadi sabun mandi. Keluliannya tersebut ia unggah ke dalam Sosial Media Twitter dan Path yang menjadi ramai diperbincangkan. Kasus kedua. Pada tanggal 5 April 2016 seorang konsumen Zalora bernama Lai Sulaiman mengalami keiugian hingga belasan juta rupiah akibat pembobolan akun zalora miliknya. Konsumen tersebut sudali beberapa bulan tidak berbelanja lagi. Namun, konsumen tersebut mendapatkan SMS dari bank penerbit karhr kreditnya bah ' va ada tranksaksi yang s'ukses di zalora. Pihak Customer Service mengatakan bahwa transaksi dilakukan melalui akunnya dan barang pesanan sudah siap untuk dikirim.. Dari 9 pesanan hanya 8 pesanan yang berhasil dibatalkan. Kasus Ketiga, Pada tanggal 28 Februari 2018 konsumen Tokopedia bemama Dedik membeli buku dan mendapatkan nomor invoice 20180228/XVIIIrtI/1 39544670. Konsumen telalr melacak barang pesanannya tersebut dengan nomor invoice yang ia miliki tetapi barang tersebut tidak dapat dilacak karena penjual telah memberikan nomor invoice palsu.

Penelitian yang memiliki relevansi deirgan penelitian ini adalah "Perbuatair Melawan Hukum oleh Lazada Indonesia Dalam Transaksi Elekhonik Dihubungkair Dengan UndangUirdang Nomor 19 Tahun 2016 Tentang Informasi dan Transaksi-

Elektronik" penelitian, dilakukan pada tahun 2017 oleh Gilang Riza Risqiandi, Mahasiswa Fakultas Hukum Universitas Pasundan. Penelitan tersebut menjelaskan bahwa prinsip-prinsip yang terdapat dalam hukum kontrak elektronik yang diatur di dalam KUHPer maupun UndangUndang ITE hampir semuanya sama, kecuali mengenai prinsip kebebasan berkontrak dimana dalam Undang-Undang ITE memiliki prinsip kebebasan berkontrak. Bahwa dalam kontrak elektronik ada barang-barang tertentu yang tidak boleh dan tidak dapat dipetjualbelikan. Adanya kebebasan kepada para pihak untuk dapat melakukan transaksi elektronik kedalam kontrak elektronik dengan benmk apa saja tetapi kontrak elektronik atau transaksi elektronik juga dibatasi, dimana para pihak harus menggunakan sistem elektronik yang telah disepakati. Dalam 
penelitian terse'but menganalisis suatu perbuatan yang dilakukan oleh pihak lazada termasuk kategori perbuatan melawan hukum atau tidak dan langka-langkah yang dapat diambil oleh konsumen sebagai pihak yang diiugikan.

Persanraan penelitian diatas dengan penelitian ini ialah, memiliki kesamaan obyek, sehingga hasil dari penelitian diatas setidaknya mampu memberikan sumbangsih ide bagi peneliti dalam menggali data terhadap informan. Perbedaannya dengan penelitian ini terletak pada fokus yang akan diteliti yakni., pelaksanaan tanggungjawab penyelenggara transaksi elektronik dal.am melindtmgi hak konsumen.

\section{B. Rumusan Masalah}

a. Bagaimana tanggungjawab penyelenggara transaksi elektronik dalam memenuhi prestasinya menurut perahrran perundang-undangan yang berlalu di Indonesia?

b. Bagaimana perlindungan konsumen dalam jual beli secara Online?

\section{Tujuan}

a. UnUrk merrgarralisis tang^mgjawab pen.yelenggara transaksi elektronik da'lam memenrrhi prestasinya menurut peraturan perundang-undangan yarrg berlalu di Indonesia.

b. Untuk menganalisis dan menjelaskan perlindungan konsumen dalam jual beli secara Online.

\section{METODE PENELITIAN}

Metode penelitian yarrg digunakan oleh penulis dalam penelitian ini adalah metode perrelitian yuridis normatif. Menurut Soeijono Soekanto dan Sri Mamudji yuridis normatif adalah perrelitian hukunr yang dilakukan dengan cara meneliti bahan kepustakaan atau data sekunder sebagai bahan dasar, untrrk ditel.iti dengan cara mengadakan penelrrsuran terhadap peraturan-peramran dan literaturliteratur yang berkaitan dengan permasalahan yang ditel'iti (M. Fajar dan Yulianto, 2009 : 34). Sedangkan pendekatan yang digunakan berdasarkan 'bahan Irrrkum utama dengan cara menelaah peraturan perundang-undangan, konseptrral, dan pendekatan kasus. Pendekatan perundang-undangan dilakukan dengan rrrenelaalr senrua undang-undang dan regulasi yang bersangkut paut dengan isu hukum yang diketengahkan (Dyah o.s. dan A'arr E., 2013 : 110). Dalanr menggunakan pendekatan konsephral pene'liti perlu merujuk prinsip-prinsip hukum yang dapat ditemukan dalam pandanganpandangarr para sarjana Irukum ataupun, doktrin-doktrin hukum, sedangkan dalam menggunakan pendekatan kasus bukan saja karena ratio decidendi-nya adalah penafsiran atau penghalusan hukum, melainkan juga dalam hal undang-undang tidak mengaturnya ((Dyah O.S. dan A'an E., 2013 : 119).

\section{HASIL PENELITIAN DAN PEMBAHASAN}

\section{A. Tanggungjawab Penyelenggara Transaksi Elektronik Dalam Memenuhi Prestasinya Menurut Peraturan Perundang-undangan Yang Berlaku Di Indonesia}

Proses transaksi jual beli online tidak jauh berbeda dengan proses transaksi jual beli secara langsung. Pelaksanaan transaksi jual beli secara online ini dilakukan dalam beberapa tahap yaitu penawaran, penerimaan, pembayaran, dan pengiriman. Pada perjanjian jual beli secara langsung kesepakatan dapat dengan mudah dilaksanakan, hanya saja dalam transaksi e-commerce, kesepakatan dalam perjanjian tersebut tidak diberikan secara langsung melainkan melalui media elektronik dalam hal ini internet. Dalam transaksi e-commerce, pihak yang memberikan 
penawaran adalah pihak penjual yang dalam hal ini menawarkan barang-barang dagangannya melalui website. Semua pengguna internet dapat dengan bebas masuk untuk melihat-lihat toko virtual tersebut atau untuk membeli barang yang mereka butuhkan.

Tahapan dalam melakukan transaksi elektronik, jika konsumen tertarik untuk membeli suatu barang maka konsumen hanya perlu mengklik barang yang sesuai dengan keinginannya. Setelah pesanan tersebut selesai maka konsumen akan mendapatkan kode pemesanan/nomor order ke alamat email yang telah didaftarkan. Tanggungjawab pelaku usaha terhadap konsumen dalam jual beli secara online secara spesifik belum diatur baik dalam UUPK maupun Undang-Undang ITE. UUPK hanya mengatur jual beli secara konvensional (tradisional) sedangkan Undang-Undang ITE mengatur tentang transaksi elektronik pada umumnya, tidak ada penyebutan khusus untuk jual beli. Pasal 19 UUPK menetapkan bahwa tanggungjawab pelalai usaha meliputi tanggungjawab ganti kerugian atas kerusakan, ganti mgi atas pencemaran dan ganti rugi atas kerugian konsumen.

Transaksi e-commerce dilakukan oleh para pihak yang terkait, walaupun para pihaknya tidak bertemu secara langsung satu sama lain melainkan berhubungan melalui media internet. Pada dasarnya para pihak dalam jual beli secara elektronik masing- masing memiliki hak dan kewajiban. Pelaku usaha merupakan pihak yang menawarkan produk melalui internet, oleh karena itu penjual bertanggungjawab memberikan informasi secara benar dan jujur atas produk yang ditawarkan kepada konsumen.

Penyelenggara agen elektronik wajib memperhatikan prinsip yang terdapat dalam Pasal 38 ayat (1) Peraturan Pemerintah tentang Penyelenggaraan Sistem dan Transaksi Elektronik (PP PSTE) menjelaskan bahwa:
a. Kehati-hatian;
b. Pengamanan dan terintegrasinya sistem teknologi informasi;
c. Pengendalian pengamanan atas aktivitas transaksi elektronik;
d. Efektivitas dan efisiensi biaya; dan 
e. Perlindungan konsumen sesuai dengan ketentuan peraturan perundang- undangan.

Para pihak yang melakukan transaksi elektronik harus menjalankan prinsip-prinsip tersebut dengan baik. Para pihak yang melanggar atau tidak dijalankan sesuai dengan prinsip-prinsip tersebut, maka pihak yang merasa dirugikan dapat meminta pertanggungjawaban dari pihak yang melanggar. Penerapan prinsip tanggungjawab mutlak sangat penting dalam hal terjadinya wanprestasi terkait dengan tingginya masalah dari para pihak pelaku usaha, tidak beritikad baik dalam berbisnis, dan banyaknya peristiwa yang menunjukan konsumen tidak dilindungi secara maksimal. Lemahnya kedudukan konsumen dalam transaksi e-commerce menjadikan tanggungjawab sepenuhnya berada ditangan pelaku usaha. Pelaku usaha akan bertanggung؛awab penuh atas kegiatan usaha yang dilakukannya dalam transaksi $e$-commerce.

Pelaku usaha mempunyai kewajiban melindungi konsumen, karena antara pelaku usaha dan konsumen telah terjadi hubungan kontraktual yang mengharuskan para pihak bertanggung؛awab apabila terjadi wanprestasi. Hal ini sesuai dengan prinsip the privity of contract, adanya hubungan kontraktual maka ada tanggungjawab. Pertanggungjawaban dalam transaksi jual beli secara elektronik maka pelaku usaha dituntut pertanggungjawabannya melalui pertanggungjawaban kontraktual (contractual liability) berkaitan dengan kerugian yang dialami oleh konsumen dan pertanggungjawaban produk (produet liability) apabila ternyata produk yang ditawarkan oleh pelaku usaha cacat dan merugikan konsumen. Konsumen yang akan meminta pertanggungjawaban mungkin akan menemukan beberapa kendala yaitu perbedaan jarak antara pelaku usaha dengan konsumen, perbedaan hukum yang dipakai jika transaksi berbeda negara, kurangnya pengetahuan konsumen tentang perlindungan konsumen dan hambatan lain apabila diterapkannya klausula baku dalam kontrak dan perlunya pembuktian untuk menuntut pertanggungjawaban pelaku usaha.

Bentuk tanggungjawab yang diberikan oleh pelaku usaha adalah ganti rugi sesuai dengan besar kerugian yang diderita oleh konsumen. Pelaku usaha yang tidak bertanggung ‘awab dalam hal melakukan wanprestasi pada transaksi e-commerce, maka konsumen dapat menempuh jalur hukum sesuai yang diatur dalam Pasal 38 ayat (1) Undang-Undang ITE tentang penyelesaian sengketa yaitu "setiap orang dapat mengajukan gugatan terhadap pihak yang menyelenggarakan sistem elektronik dan/atau menggunakan teknologi informasi yang menimbulkan kerugian" dan Pasal 39 ayat (2) Undang-Undang ITE yaitu "penyelesaian gugatan perdata sebagaimana dimaksud pada ayat (1), para pihak dapat menyelesaikan sengketa melalui arbitrase, atau lembaga penyelesaian sengketa alternatif lainnya sesuai dengan ketentuan peraturan perundangundangan'. Selain itu, konsumen juga dapat melaporkan pada pihak yang berwajib (jalur pidana) bahwa tindakan tersebut adalah suatu tindak pidana penipuan terkait Pasal 378 KUHP. Pembuktian ada tidaknya unsur kesalahan dalam kasus pidana dan/atau tuntutan ganti rugi yang terkait dengan masalah perlindungan konsumen merupakan beban dan tanggungjawab pelaku usaha. Khusus untuk kasus pidana, jaksa tetap mempunyai hak untuk melakukan pembuktian. Pelaku usaha yang menolak dan/atau tidak memberi tanggapan dan/atau tidak memenuhi ganti rugi atas tuntutan konsumen, maka pelaku usaha dapat digugat melalui Badan Penyelesaian Sengketa Konsumen (BPSK) atau mengajukan ke badan peradilan di tempat kedudukan konsumen. Indonesia mempunyai banyaknya layanan e-commerce, salah satu yang terkenal adalah toko online Lazada, Zalora, dan Tokopedia. Marketplace tersebut memiliki layanan yang dapat dimanfaatkan oleh konsumen antara lain:

a. Layanan online chat 24 jam 
Konsumen dapat menghubungi customer setwice 24 jam jika terdapat keluhan- keluhan yang dialami oleh konsumen.

b. Gratis biaya kirim ke seluruh Indonesia

Marketplace memberikan gratis ongkos pengiriman ke seluruh Indonesia dengan minimum akumulasi pembelian.

Kelebihan yang dimilikinya tersebut, tidak dapat dipungkiri akan adanya risiko- risiko yang akan dihadapi oleh konsumen seperti layanan M-banking dan pembayaran kartu kredit yang belum memiliki integritas tinggi. Pada dasarnya penyelenggara transaksi elektronik telah menggunakan sistem pengaman optimal, baik transaksi yang disediakan bank, virtual payment, atau uang elektronik (e-money). Akan tetapi ancaman kejahatan di dunia maya (cyber crime) masih tetap terjadi pada pengguna transaksi elektronik. Konsumen yang memilih pembayaran melalui M-banking maupun kartu kredit karena sistem pembayaran yang dilakukan dengan mudah, praktis dan cepat. Konsumen hanya menentukan barang apa yang dibutuhkan di Windows shopping dan memasukkan nomor kartu kreditnya.

Pihak penyelenggara, konsumen dan pihak penerbit kartu kredit memiliki hak dan kewajiban yang lahir dari perjanjian yang telah disepakatinya. Para pihak berkewajiban untuk memenuhi segala hak dan kewajiban tersebut. Perjanjian yang dibuat secara sah akan mengikat para pihak seperti undang-undang walaupun dalam perjanjian tersebut tidak diatur mengenai kewajiban bagi penyelenggara dan pihak penerbit kartu kredit untuk menyediakan suatu sitem pengamanan. Konsumen seharusnya tetap berhak menuntuk agar dalam suatu transaksi $e$-commerce tersedia suatu sistem pengamanan yang baik sesuai dengan kepatutan dalam masyarakat, karena perjanjian bukan hanya mengikat untuk hal-hal yang secara tegas diperjanjikan tetapi juga diharuskan oleh kepatutan, kebiasaan, dan undang-undang.

Undang-Undang ITE masih memiliki kelemahan salah satunya tidak mencakup masalah operasional perbankan khususnya kegiatan perbankan yang memiliki potensi kejahatan dunia maya antara lain adalah layanan online shopping (berbelanja secara otiline) yang memberikan fasilitas pembayaran melalui kartu kredit. Jenis kejahatan ini teijadi akibat kemudahan sistem pembayaran menggunakan kartu kredit yang diberikan penyelenggara. Akan tetapi, UUPK telah mengatur mengenai asas keamanan dan keselamatan bagi konsumen. Asas ini adalah asas yang tepat untuk digunakan sebagai perlindungan hukum bagi konsumen pemegang kartu kredit dalam transaksi elektronik.

Hubungan hukum pada transaksi elektronik teijadi pada saat tereapainnya kesepakatan para pihak. Para pihak yang telah melakukan kesepakatan maka pihak- pihak tersebut mempunyai hak dan kewajiban yang harus dipenuhi. Pasal 50 ayat (3) Undang-Undang ITE menjelaskan bahwa kesepakatan tersebut dapat dilakukan dengan cara:

a. Tindakan penerimaan yang menyatakan persetujuan atau;

b. Tindakan penerimaan dan/atau pemakaian objek oleh pengguna Sistem Elektronik.

Transaksi elektronik semakin diminati, bahkan sudah menjadi tren di kalangan masyarakat luas. Selain dapat dilakukan kapanpun dan dimanapun tanpa ada batasan waktu maupun jarak. Semakin berkembangnya marketplace, semakin beragam pula metode pembayaran yang biasa digunakan untuk melakukan transaksi elektronik. Konsumen semakin mengenal metode pembayaran tidak hanya melalui transfer bank, kartu kredit, atau cas $h$ o $n$ delivery (COD), tetapi 
juga metode pembayaran via mobile wallei atau aplikasi mobile sejenis lainnya.

Proses penawaran dan penerimaan yang dikelola oleh sistem penyelenggara elektronik akan berjalan dengan baik jika didukung oleh keamanan dan kelancaran jaringan, sesuai dengan pasal 15 Undang-Undang ITE yang menjelaskan bahwa sistem penyelenggaraan informasi dan transaksi elektronik harus dilakukan secara aman, andal dan dapat beroperasi sebagaimana mestinya. Penyelenggaraan sistem elektronik bertanggung!awab atas sistem yang diselenggarakannya. Pasal 10 ayat (1) Undang- Undang ITE dijelaskan bahwa "setiap pelaku usaha yang menyelenggarakan transaksi elektronik dapat disertifikasi oleh lembaga sertifikasi keandalan". Pasal 16 Undang- Undang ITE menjelaskan bahwa sepanjang tidak ditentukan lain oleh undang-undang tersendiri, setiap penyelenggaraan sistem elektronik wajib mengoprasikan sistem elektronik yang memenuhi persyaratan minimum sebagai berikut:

a. Dapat menampilkan kembali informasi elektronik dan/atau dokumen elektronik secara utuh sesuai dengan masa retensi yang ditetapkan dengan peraturan perundang-un dangau;

b. Dapat melindungi ketersediaan, keutuhan, keotentikan kerahasiaan dan keteraksesan informasi elektronik dalam penyelenggaraan sistem elektronik tersebut;

c. Dapat beroperasi sesuai dengan prosedur atau petunjuk dalam penyelenggaraan sistem elektronik tersebut;

d. Dilengkapi dengan prosedur atau petunjuk yang diumumkan dengan bahasa, informasi, atau simbol yang dapat dipahami oleh pihak yang bersangkutan dengan penyelenggaraan sistem elektronik tersebut; dan

e. Memiliki mekanisme yang berkelanjutan untuk menjaga kebaruan, kejelasan, dan pertanggungjawaban prosedur atau petunjuk.

Penyelenggara transaksi elektronik sudah sepatutnya mengikuti aturan yang sudah diatur dalam KUHPer, Undang-Undang ITE, UUPK, PP PSTE. Sehamsnya tanggungjawab penyelenggara transaksi elektronik dapat langsung dirasakan oleh konsumen yang dirugikan oleh penyelenggara transaksi elektronik. 


\section{B. Perlindungan Konsumen Dalam Jual Secara Online}

Perlindungan hukum pada jual beli secara Online menjadi perhatian penting khususnya perlindungan terhadap konsumen karena banyak kasus kerugian yang dialami oleh konsumen. Mengenai barang yang tidak sesuai dengan informasi yang diterima atau tidak dikirimnya barang yang sudah dilakukan pembayaran oleh pembeli atau dengan kata lain sering terjadinya wanprestasi yang dilakukan oleh pelaku usaha sehingga merugikan pihak lain. Wanprestasi yang sering dilakukan oleh pihak pelaku usaha yaitu banyak pihak pelaku usaha yang mengkesampingkan hak-hak konsumen yang telah diatur dalam Pasal 4 UUPK, yang menyatakan bahwa:

a. Hak atas kenyamanan, keamanan, dan keselamatan dalam mengkonsumsi barang dan/atau jasa;

b. Hak untuk memilili barang dan/atau jasa serta mendapatkan barang dan/'atau jasa tersebut sesuai dengan nilai tukar dan kondisi serta jaminan yang dijanjikan;

c. Hak atas informasi yang benai., jelas, dan jujur mengenai kondisi dan jaminan barang dan/atau jasa;

d. Hak untuk didengan pendapat dan keluhannya atas barang dan/atau jasa yang digunakair;

e. Hak unmk mendapatkan advokasi, perlindungan, dan upaya penyelesaian sengketa perlindungan konsumen secara patut;

f. Hak untuk meirdapat pembinaan dan pendid'ikan konsumen;

g. Hak untuk diperlakukan atau dil.ayani secara benar- dan jujur serta tidak diskriminatif;

lr. Hak untuk mendapatkan kompensasi, ganti rugi dan/atau penggantian, apabila barang dan/atau jasa yang diterima tidak sesuai derrgan perjanjian atau tidak sebagaimana mestinya;

i. Hak-lrak yang diatur dalam ketentuan peraturan perundang-undangan lai'nnya.

Konsumen selain memperoleh hak, sebagai balance juga diwajibkan untuk membaca dan mengikuti petunjuk informasi dan prosedur pemakaian atau pemanfaatan barang dan/atau jasa demi keamanan dan keselamatan, bertitikad baik dalam melakukan transaksi pembelian barang dan/atau jasa., pembayaran sesuai dengan nilai trrkar yang disepakati, mengikuti upaya penyelesaian hukum sengketa perlindungan konsumerr sec-ara patut (Dahlia, 2009 : 40). Konsrrmen dan pelaku usalra merupakan pihak-pihak yang harus mendapatkan perlindungan hukum. Namun, posisi konsumen pada umumnya lemah dibandingkan dengan pelaku usalra. Hal ini berkaitan dengan tingkat kesadaran akan haknya dan kemampuanfmancial. Posisi konsumen harus dilindrrngi oleh hukum, karena salah satrr sifat dan tujuan, hukum adalah memberikan pe'lindungan (pengayoman) kepada masyarakat. Perlindrrngan kepada masyarakat tersebut harus diwujudkan dalam bentuk kepastian hukum yang menjadi Irak konsrrmen.

Konsumen dalam melakukan trarrsaksijual beli secara orrline harus jeli, teliti, serta waspada terhadap penawaran yang dilakukan oleh pelaku usaha. Tidak jarang pelaku usaha menawarkan produk yang fiktif, yang dijual murah agar konsumen tertarik. Konsumen harus menrastikan dalrulu sebelum memesan barang, pastikan merchant memiliki nilai rating yang baik. Apabila tertarik dengan barang yang ditawarkannya, maka lakukan komunikasi terlebih dahulu untuk memastikan apakah barang benar-benar ada, setelah itu konsumen menanyakan tentang 
spesifikasi barang yang akan dibelinya. Jika setuju, maka konsumen segera membayar harga atas barang tersebut kemudian barang akan dikirimkan. Kegiatan aktif konsumen untuk selalu berkomunikasi atau bertanya tentang barang yang akan dibelinya kepada pelaku usaha akan dapat mengurangi dampak kerugian bagi konsumen.

Pada dasarnya UUPK sudah sangat efektif mengatur mengenai hak-hak konsumen, sehingga jika terdapat hal-hal yang melanggar hukum yang dilakukan oleh pelaku usaha konsumen dapat menuntut haknya. Hanya saja pada jual beli secara transaksi elektronik pihak konsumen bersifat pasif dan pasrah akan kejadian yang menimpanya mengingat transaksi elektronik ini sangat sulit bagi konsumen yang ingin menuntut akan haknya. Hal ini dikarenakan rendahnya kesadaran dan pengetahuan konsumen, tidak mustahil dijadikan lahan bagi pelaku usaha dalam transaksi yang tidak mempunyai itikad baik dalam menjalankan usaha, yaitu berprinsip mencari keuntungan yang sebesar-besarnya dengan memanfaatkan seefisien mungkin sumber daya yang ada.

Transaksi jual beli yang dilakukan secara online, berdasarkan Undang-Undang ITE dan PP PSTE tetap diakui sebagai transaksi elektronik yang dapat dipertanggungjawabkan. Persetujuan untuk membeli barang secara online dengan cara melakukan klik persetujuan atas transaksi merupakan bentuk tindakan penerimaan yang menyatakan persetujuan dalam kesepakatan pada transaksi elektronik. Tindakan penerimaan tersebut biasanya didahului pernyataan persetujuan atas syarat dan ketentuan jual beli secara online yang dapat dinyatakan juga sebagai salah satu bentuk kontrak elektronik.

Kontrak elektronik elektronik pada umumnya dibuat dalam bentuk baku (Standard contract) oleh pihak penyelenggara, sehingga pihak konsumen tidak berhak untuk mengubah isi kontrak baku tersebut. Pihak konsumen hanya tinggal membaca isi kontrak baku dan jika tidak setuju konsumen tidak akan melanjutkan transaksi. Kontrak baku sudah biasa dilakukan di dunia bisnis karena pertimbangan kebutuhan dan kepraktisan. Namun demikian, kontrak baku tersebut tetap tidak boleh bertentangan dengan KUHPerdata, Undang-Undang ITE, dan UUPK.

Perjanjian baku dengan klausula eksonerasinya pada prinsipnya hanya menguntungkan pelaku usaha dan merugikan konsumen, karena klausulanya tidak seimbang dan tidak mencerminkan keadilan. Perjanjian eksonerasi yang membebaskan tanggungjawab seseorang pada akibat-akibat hukum yang terjadi karena kurangnya pelaksanaan kewajiban-kewajiban yang diharuskan oleh perundang-undangan. Akibat kedudukan para pihak yang tidak seimbang, maka pihak yang lemah biasanya tidak berada dalam keadaan yang benar-benar bebas untuk menentukan apa yang diinginkan dalam perjanjian, dengan hal demikian, pihak yang memiliki posisi yang lebih kuat biasanya menggunakan kesempatan tersebut untuk menentukan klausulaklausula tertentu dalam peijanjian baku. Sehingga perjanjian yang seharusnya dibuat oleh para pihak yang terlibat didalam perjanjian, tidak ditemukan lagi dalam bentuk perjanjian 
baku, karena format dan isi perjanjian telah dirancang oleh pihak yang kedudukannya yang lebih kuat.

UUPK menginginkan terciptanya keseimbangan antara konsumen dengan pelaku usaha. Pengaturan pencantuman klausula baku bukanlah merupakan keberpihakan terhadap kepentingan konsumen dan merugikan kepentingan pelaku usaha. Namun asas keseimbangan dalam hukum perlindungan konsumen, menginginkan kepentingan semua pihak harus dilindungi, termasuk kepentingan pemerintah dalam pembangunan nasional. Dalam perjanjian jual beli elektronik klausula baku dapat ditemui dalam term and condition dimana pelalai usaha mencantumkannya ditempat pihak konsumen tidak dapat terlihat. Hal ini terjadi karena kurangnya ilmu pengetahuan tentang jual beli secara elektronik sehingga konsumen dikatakan pihak yang kedudukannya lemah dalam jual beli secara elektronik.

Perjanjian baku sangat dibutuhkan dalam dunia perdagangan yang semakin pesat. Dengan penggunaan klausula baku tersebut, berarti para pihak dapat mempersingkat waktu bernegoisasi. Upaya perlindungan konsumen sangatlah terbatas dan tidak mungkin memberikan perlindungan konsumen kepada konsumen secara keseluruhan. AJcan tetapi upaya tersebut dapat dijadikan untuk membatasi kerugian akibat penggunaan klausula baku. Pembatasan atau larangan pencantuman klausula balai tertentu dalam perjanjian tersebut, dimaksudkan untuk mencegah terjadinya penyalahgunaan keadaan oleh pihak yang memiliki kedudukan lebih kuat, yang pada akhirnya akan merugikan konsumen.

Dengan demikian, pada transaksi elektronik yang dilakukan dapat menggunakan instrument Undang-Undang ITE dan/atau PP PSTE sebagai dasar hukum dalam menyelesaikan permasalahan. Ada beberapa contoh kasus yang terjadi di situs marketplace: Kasus pertama, Dannis Damsman sebagai konsumen Lazada membeli sebuah handphone bermerek Iphone 6+ seharga Rp. 12.000.000,- pada marketplace Lazada. Namun, saat barang pesanan pembeli tiba yang diterima oleh konsumen bukanlah handphone melainkan sabun mandi. Pada kasus ini pelaku usaha telah melakukan wanprestasi dimana pelaku usaha melaksanakan apa yang dijanjikan, tetapi tidak sebagaimana dijanjikan.

Kasus diatas dapat diselesaikan dengan cara damai antara pihak konsumen dengan pihak pelaku usaha. Pihak pelaku usaha bertanggung !awab penuh kepada konsumen dengan memberikan apa yang sebagaimana sudah diperjanjikan yaitu handphone dengan merek Iphone 6+. Dalam hal ini konsumen harus teliti dan berhati-hati terhadap pelaku usaha yang tidak mempunyai itikad baik. Konsumen harus memiliki pengetahuan dan cermat dalam melakukan perjanjian jual beli, ada kalanya pelaku usaha membuat term and condition pada kontrak yang bersifat klausula baku yang tidak sesuai dengan undang-undang. Sehingga dampak yang ditimbulkan adalah kerugian konsumen dan sudah sepatutnya pelaku usaha berkewajiban memenuhi semua tanggung؛awabnya sebagaimana yang tertuang dalam Pasal 7 UUPK apabila ia terbukti melakukan kesalahan. 
Kasus kedua, konsumen Zalora bernama Lai Sulaiman mengalami kerugian hingga belasan juta rupiah akibat pembobolan akun zalora miliknya. Konsumen tersebut sudah beberapa bulan tidak berbelanja lagi. Namun, konsumen tersebut mendapatkan SMS dari bank penerbit kartu kreditnya bahwa ada tranksaksi yang sukses di zalora. Pihak Customer Service mengatakan bahwa transaksi dilakukan melalui akunnya dan barang pesanan sudah siap untuk dikirim, dari 9 pesanan hanya 8 pesanan yang berhasil dibatalkan.

Konsumen yang mempunyai masalah dalam penggunaan kartu kredit sehingga mengakibatkan kerugian yang dalam hal bukan dikarenakan kesalahan dari konsumen maka pelalai usaha wajib mengganti kerugian sebagaimana hal tersebut telah diatur dalam Pasal 7 huruf f UUPK yang berbunyi, "memberi kompensasi, ganti rugi dan/atau penggantian atas kemgian akibat penggunaan, pemakaian dan pemanfaatan barang dan/atau jasa yang diperdagangkan".

UUPK telah mengatur mengenai asas keamanan dan keselamatan kepada konsumen dalam penggunaan, pemakaian dan pemanfaatan barang dan/atau jasa yang dikonsumsi atau digunakan. Asas ini jika diterapkan dalam perjanjian penggunaan kartu kredit, bahwa pemegang kartu akan merasa nyaman dan aman selama menggunakan fasilitas kartu kredit dari penerbit. Pada umumnya konsumen tidak mengetahui tanggungjawab yang diatur dalam UUPK dan konsumen tidak mengetahui hak dan kewajiban sebagai konsumen apabila teijadi masalah dalam penggunaan kartu kredit. Kurangnya sosialisasi terhadap aturan-aturan hukum yang terjadi sehingga konsumen tidak memahami perlindungan hukum apabila konsumen mengalami kerugian terutama masalah kartu kredit.

Kasus Ketiga, konsumen Tokopedia bernama Dedik membeli buku dan mendapatkan nomor invoice 20180228/XVIII/II/139544670. Konsumen telah melacak barang pesanannya tersebut dengan nomor invoice yang ia miliki tetapi barang tersebut tidak dapat dilacak karena penjual telah memberikan nomor invoice palsu. Pasal 7 huruf b UUPK menjelaskan bahwa pelaku usaha berkewajiban memberikan informasi yang benar, jelas, dan jujur mengenai kondisi dan jaminan barang dan/atau jasa serta memberikan penjelasan penggunaan, perbaikan dan pemeliharan. Sehalusnya pada kasus ini pelaku usaha harus memberikan informasi mengenai nomor invoice, pelaku usaha yang memberikan nomor invoice palsu telah merugikan konsumen yang telah melakukan pembayaran dan konsumen berhak mendapatkan ganti rugi.

Pelaku usaha yang telah melanggar ketentuan UUPK maka konsumen berhak mengajukan gugutan melalui badan penyelesaian sengketa konsumen atau mengajukan ke peradilan di tempat kedudukan konsumen. Konsumen diberikan hak untuk menggugat pelaku usaha dan menyelesaikan perselisihan yang timbul melalui Badan Penyelesaian Sengketa Konsumen (BPSK) atau dengan cara mengajukan gugutan kepada peradilan ditempat kedudukan konsumen tersebut (Cita Y.S., 2013 . 144). Dalam upaya penyelesaian sengketa konsumen menurut Pasal 52 UUPK terdapat dua pilihan, yaitu: 
a. Melalui lembaga yang bertugas menyelesaikan sengketa antara konsumen dan pelaku usaha (dalam hal ini BPSK); atau

b. Melalui peradilan yang berada di lingkungan peradilan umum.

Konsumen juga dapat mengajukan gugutan secara perwakilan terhadap pihak yang menyelenggarakan sistem elektronik dan/atau menggunakan teknologi informasi yang berakibat merugikan masyarakat sesuai dengan ketentuan peraturan perundang- undangan. Dalam transaksi e-commerce, keadaan yang tidak diinginkan ini teijadi kerugian khususnya kerugian pada pihak konsumen. Upaya hukum preventif perlu untuk diterapkan mengingat penyelesaian sengketa $e$ commerce relatif sulit, memerlukan waktu yang lama dalam penyelesaiannya dan tidak jarang memerlukan biaya yang tinggi. Maka dari itu, sengketa e-commerce sebisa mungkin harus dicegah. Dalam usaha-usaha untuk mencegah terjadinya kerugian perlu adanya pembinaan konsumen yang terdapat didalam Pasal 29 ayat (1) UUPK.

Pembinaan terhadap konsumen bertujuan agar konsumen mengetahui hak-haknya sebagai konsumen dan mendorong pelaku usaha agar menjual produknya secara sehat. Dalam era Informasi Teknologi (IT) seperti saat ini, pembinaan konsumen harus ditingkatkan mengingat bahwa edukasi adalah pertahanan terbaik untuk mengatasi cyber crime, karena ancaman pelanggaran terhadap hakhak konsumen tidak hanya berasal dari pelaku usaha saja tapi bisa juga datang dari pihak ketiga melalui kejahatan- kejahatan internet. Penyelenggara transaksi elektronik sudah sepatutnya mengikuti aturan yang sudah diatur di dalam peraUiran pemndang-undangan. Konsumen berhak mendapatkan perlindungan hukum dalam melalaikan transaksi elektronik. KESIMPULAN DAN SARAN A. Kesimpulan

Tanggung !awab penyelenggara transaksi elektronik dalam memenuhi prestasinya menurut UUPK meliputi tanggung !awab atas kerusakan, tanggung ؛awab atas pencemaran dan tanggung!awab atas kerugian konsumen. Konsumen juga dapat menempuh jalur hukum dengan mengajukan gugutan terhadap pelaku usaha sesuai dengan peraturan perundang-undangan yang mengatur mengenai perbuatan tersebut yakni KUHPer, UUPK, Undang-Undang ITE dan PP PSTE. Selain itu, konsumen dapat menempuh jalur pidana dengan melakukan pelaporan terhadap pihak yang berwajib dengan tuduhan tindak pidana penipuan. Bentuk perlindungan konsumen dalam jual beli secara online telah diatur di dalam UUPK dan Undang-Undang ITE bahwa konsumen berhak mendapatkan informasi yang benar, jelas, dan jujur mengenai kondisi dan jaminan barang dan/atau jasa. Bentuk perlindungan konsumen juga meliputi sistem keamanan, pengembalian produk (return) dan pengembalian dana (refund) yang telah sesuai dengan aturan hukum positif. Namun, penyelenggara transaksi elektronik mempunyai aturan lain yang masih belum sesuai, seperti implementasi pengembalian dana (refund) yang belum sesuai; penggantian voucher sebagai ganti rugi yang belum tentu sesuai dengan kehendak konsumen; terjadi pembatalan sepihak oleh pihak penjual; pembatasan tanggung ؛awab terhadap kerugian konsumen. 


\section{B. Saran}

Dalam menawarkan barang dan/atau jasa hendaknya penyelenggara transaksi elektronik dapat menjaga kepercayaan para konsumen selringga dengan adanya kepercayaan maka tidak te^adi sengketa tran-saksi melalui media elektronik' (internet). Konsumen selaku pembeli yang ingin melakukan transaksi jual beli melalui internet agar lebih berhati-hati dalam melalaikan transaksi sebelum deal ordei.. Penyelenggara transaksi elektronik dapat mengevaluasi kontrak baku menge-nai implementasinya sehingga pelaksanaan transaksi dapat beija'lan dengan baik dan diharapkan lebih memprioritaskan konsumen jika teijadi kerugian sebagai benmk perlindungan hukum.

\section{DAFTAR PUSTAKA}

Cita Yustisia Serfiani, IR. R. Serfianto D. Purnomo, dan Iswi Ilariyani, Bisnis Online dan Transaksi Elektronik, Jakarta: Gramedia Pustaka Utama, 2016

Dahlia, "Perlindungan Konsumen Terhadap Tmsaksi Jual Beli, Melalui Media Internet (E- commerce)", Wacana Hukum, vol.8, no.1, 2009

Dyah Ochtorina Susanti dan A'an Efendi, Penelitian Hukum, Surabaya, 2013.

Mariam, Darus Badrulzaman, et.a'l.. Kompilasi Hukum Perikatan, Bandung: Citra Aditya Bakti, 2001

Mukti Eajar dan Yulianto Achmad, Dualisme Penelitian Hukum Normatif \& Empiris, Yogyakarta: Pustaka Pelajar, 2009.

Siswanto Sunarso, Hukum informasi Dan Transaksi Elektronik, Jakarta: Rineka Cipta, 2009 